\title{
Western redcedar population dynamics in old-growth forests: Contrasting ecological paradigms using tree rings ${ }^{1}$
}

\author{
by Lori D. Daniels ${ }^{2}$
}

In coastal British Columbia, late-successional forests dominated by western redcedar (Thuja plicata Donn ex D. Don) are structurally complex, with deep multi-layered canopies, large trees that are $>250$ years old, and abundant coarse woody debris (CWD). These forests are presumed to be "old-growth" forests in which fine-scale gaps are the dominant disturbance regime, accounting for their structural diversity. In this study, I have used tree-ring analyses to investigate western redcedar regeneration dynamics in these old-growth forests. Western redcedar dominates canopies of many stands, but is rare in the understorey although it tolerates shade. The traditional interpretation is that western redcedar depends on catastrophic disturbance to regenerate and that it is replaced through succession by western hemlock (Tsuga heterophylla (Raf.) Sarg.) and Pacific silver fir (Abies amabilis (Dougl. ex Loud.) Dougl. ex J. Forbes), which are abundant in the understorey. Dominant trees are perceived to represent an even-aged, post-disturbance cohort and the lack of regeneration indicates a population decline in the absence of catastrophic disturbances. In this paper, I investigate four assumptions underlying this interpretation: (1) Tree size indicates age. (2) Populations establish as even-aged, post-disturbance cohorts. (3) Abundant CWD represents recent mortality. (4) Regeneration is insufficient to maintain canopy dominance. Using tree-ring evidence, I show that population dynamics of western redcedar are a combination of gap-phase establishment and a continuous mode of recruitment from the subcanopy to the canopy. Specifically, size is a poor surrogate for tree age. Age distributions from 15 sites revealed uneven-aged populations, rather than single post-disturbance cohorts. Both logs and snags of western redcedar may persist more than 270 years; they do not represent recent mortality that is disproportionate to the number of live western redcedar in canopy. The regeneration niches of western redcedar and western hemlock overlap. For both species, gap-phase disturbances result in substrate suitable for successful seedling establishment. Preliminary results from dendroecological analysis of radial growth rates of trees in the subcanopy and canopy strata suggest that western hemlock and Pacific silver fir depend on gaps to recruit to the upper canopy, but recruitment of western redcedar may be independent of canopy gaps. I propose that differences in mode of recruitment to the canopy may explain the differences in population structures between western redcedar, western hemlock, and Pacific silver fir in the old-growth forest. These results provide an ecological precedent for use of a range of silvicultural systems, including clearcuts through single-tree harvesting and protection forests, when managing western redcedar in coastal British Columbia.

Key words: Coastal British Columbia, disturbance regimes, regeneration dynamics, Thuja plicata, variable retention silviculture

Dans la région côtière de la Colombie-Britannique, les forêts de fin de succession dominées par le thuya géant (Thuja plicata Donn ex D. Don) possèdent une structure très complexe qui comprend un couvert forestier à strates multiples, de gros arbres âgés de plus de 250 ans et une abondance de débris ligneux grossiers. On présume qu'il s'agit de forêts anciennes dans lesquelles les trouées à petite échelle constituent le principal régime de perturbation, qui serait à l'origine de leur diversité structurale. Dans cette étude, j'ai effectué des analyses des cernes pour examiner la dynamique de régénération du thuya géant dans ces forêts anciennes. Cette essence domine l'étage supérieur de nombreux peuplements, mais elle est rare dans le sous-étage, bien que tolérante à l'ombre. L'explication traditionnelle est que le thuya géant dépend des perturbations catastrophiques pour se régénérer et que, dans le processus de succession, il est remplacé par la pruche de l'Ouest (Tsuga heterophylla (Raf.) Sarg.) et le sapin gracieux (Abies amabilis (Dougl. ex Loud.) Dougl. ex J. Forbes) qui sont abondants dans le sous-étage. On considère que les arbres dominants représentent une cohorte équienne établie après une perturbation, et que l'absence de régénération indique un déclin de la population en l'absence de perturbation catastrophique. Dans cette étude, je vérifie quatre hypothèses à la base de cette explication : 1) la taille des arbres est un indicateur de l'âge; 2) les populations sont constituées de cohortes équiennes établies après une perturbation; 3) l'abondance de débris ligneux grossiers témoigne d'une mortalité récente; 4) la régénération est insuffisante pour assurer le maintien de la dominance du couvert par le thuya géant. À l'aide de données sur les cernes, je montre que la dynamique des populations de thuya géant est une combinaison de la régénération par trouées et d'un mode de recrutement continu à partir de la strate inférieure du couvert. La taille d'un arbre est un mauvais indicateur de son âge. Les distributions d'âges déterminées pour 15 sites révèlent des populations inéquiennes plutôt que des cohortes uniques issues d'une perturbation. Le bois mort et les chicots de thuya géant peuvent persister plus de 270 ans et ils ne représentent pas une mortalité récente disproportionnée par rapport au nombre d'arbres vivants présents dans le couvert forestier. Les niches de régénération du thuya géant et de la pruche de l'Ouest se chevauchent. Les perturbations produisant des trouées créent un substrat approprié à l'établissement des semis des deux espèces. D'après les résultats préliminaires d'une analyse dendroécologique de la croissance radiale des arbres des strates inférieure et supérieure du couvert, la pruche de l'Ouest et le sapin gracieux dépendraient des trouées pour leur recrutement à la strate supérieure du couvert, tandis que le recrutement du thuya géant en serait indépendant. Je propose que les différences dans le mode de recrutement à la strate supérieure peuvent expliquer les différences dans la structure des populations du thuya géant, de la pruche de l'Ouest et du sapin gracieux dans la forêt ancienne. Ces résultats constituent un précédent écologique pour l'utilisation d'un ensemble de régimes sylvicoles (notamment coupes à blanc, récolte d'arbres individuels et forêts de protection) dans le cadre de la gestion du thuya géant dans la région côtière de la Colombie-Britannique.

Mot clés : Côte de la Columbie-Britannique, Thuja plicata, rétention variable

\footnotetext{
${ }^{1}$ Paper presented at the "Old-growth Forests in Canada: A Science Perspective" Conference, October 14-19, 2001, Sault Ste. Marie, ON.

${ }^{2}$ Department of Geography, University of British Columbia, 217-1984 West Mall, Vancouver, British Columbia V6T 1Z2. E-mail: daniels@ geog.ubc.ca
} 


\section{Introduction}

\section{Succession and disturbance regimes}

In the latter part of the $20^{\text {th }}$ century, ecological theory underwent a major revolution that has influenced our understanding of vegetation dynamics, biodiversity conservation, and management of biological resources (Glenn-Lewin et al. 1992, Pickett et al. 1992). Three major trends in our understanding of vegetation dynamics emerged as part of the new, contemporary paradigm. (1) Non-equilibrium dynamics. Contemporary successional theory states that vegetation change is the outcome of populations interacting with one another within a fluctuating environment (Glenn-Lewin et al. 1992). Disturbance at a range of spatio-temporal scales is frequent and integral to vegetation change (White 1979, Sousa 1984, Pickett and White 1985). Deterministic trajectories, long-term environmental stability, and an endpoint to succession are no longer assumed (Glenn-Lewin et al. 1992). (2) Multiple-scale approach. A reductionist approach has focused on mechanisms and proximate causes of vegetation change. Such research investigates process rather than endpoints or outcomes of change (Glenn-Lewin et al. 1992). The importance of multi-scalar processes is now widely acknowledged, resulting in new approaches and disciplines such as landscape ecology (Pickett et al. 1987, Pickett and Kolasa 1989, Glenn-Lewin et al. 1992). (3) Human impacts. Humans are now explicitly recognized as agents of disturbance and an important source of variation in vegetation dynamics (Pickett et al. 1992).

This paradigm shift has profoundly changed our understanding of late-successional or old-growth forest communities. According to the classical paradigm, old-growth or "climax" forests develop under stable conditions and in the absence of disturbance. In contrast, contemporary models of forest development acknowledge the ubiquitous influence of fine-scale canopy-gap disturbances in late-successional forests (Oliver 1981, Oliver and Larson 1990, Franklin et al. 2002). In this context, Wells et al. (1998) have defined "old growth" as a forest in which processes of gap dynamics predominate. Old-growth forests develop as trees recruit from the understorey to the canopy under the influence of frequent, fine-scale canopy-gap disturbances. According to this contemporary definition, "old-growth" is a dynamic ecological process driven by disturbance, rather than a stable endpoint or outcome of change. This definition is particularly powerful as it acknowledges that developmental processes are the proximate cause of structural attributes such as large range of tree sizes, horizontal and vertical structural complexity in the canopy, and accumulation of course woody debris (CWD) (Wells et al. 1998). In turn, these structural attributes can be used as surrogates to identify old-growth forests when detailed knowledge of ecological process is not available for a specific location. In this study, I demonstrate how this contemporary definition of old growth can be used to improve our understanding of the western redcedar-dominated forests of coastal British Columbia.

\section{Old-growth forests of coastal British Columbia}

Old-growth forests exist where stand-replacing disturbances are sufficiently rare that an uneven-aged forest develops under the influence of fine-scale canopy gaps. As stand-level disturbances are common in many forest types (White 1979, Sousa 1984), landscapes dominated by old-growth forests are relatively rare. Under the influence of a cool, wet climate, catastrophic disturbance (i.e., fire) is infrequent in coastal British Columbia, thus old-growth forests dominate many landscapes (Lertzman et al. 1996, Pojar et al. 1999). These landscapes afford a unique opportunity to examine canopy gap disturbance regimes at a range of spatial scales and to study the mechanisms that underlie community structure and composition.

Linked to our understanding of disturbances as agents of

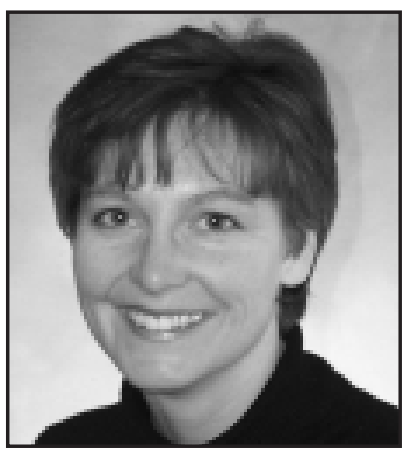

Lori D. Daniels temporal change in coastal old-growth forests are questions pertaining to population dynamics and successional trajectories. In submontane forests of the very wet maritime Coastal Western Hemlock subzone of British Columbia, old-growth stands are often composed of western redcedar (Thuja plicata Donn ex D. Don), western hemlock (Tsuga heterophylla (Raf.) Sarg.), and Pacific silver fir (Abies amabilis (Dougl. ex Loud.) Dougl. ex J. Forbes), and sometimes Douglas-fir (Pseudotsuga menziesii (Mirb.) Franco var. menziesii) (Pojar et al. 1991). Canopy trees grow to heights exceeding $60 \mathrm{~m}$ and diameters of up to $350 \mathrm{~cm}$, and live more than 1000 years. Canopy structure is complex vertically and horizontally, with canopy gaps related to snags and downed trees.

In the wet coastal environment, Douglas-fir is shade-intolerant, thus it establishes following catastrophic stand-level disturbances (Klinka et al. 1990, Carter and Klinka 1992) and dominates late-successional stands by virtue of its longevity (Munger 1940, Franklin and Hemstrom 1981, Kuiper 1988). Western redcedar, western hemlock, and Pacific silver fir are exposure-tolerant, with vigorous growth in full sunlight, and yet shade-tolerant and able to grow beneath old-growth canopies (Klinka et al. 1990, Carter and Klinka 1992). Western redcedar dominates many old-growth forest canopies but is rare in the understorey, although it tolerates shade (Schmidt 1955, Gregory 1957, Franklin and Dyrness 1973, Keenan 1993, Daniels 1994). The traditional successional paradigm for these forests is based on equilibrium concepts. In the absence of catastrophic disturbance, western redcedar is replaced by western hemlock and Pacific silver fir, which are abundant in the understorey and subcanopy strata of the forest. Western hemlock and Pacific silver fir are considered the "climatic climax" species, and western redcedar is a "seral" species, with its populations sustained only on edaphically unique sites (Krajina 1969). The interpretation that western redcedar populations are replaced through succession implies that this species, like Douglas-fir, relies on catastrophic, stand-level disturbance to regenerate (Krajina 1969, Pojar et al. 1991).

Several field observations appear consistent with the interpretation that western redcedar exhibits a "catastrophic mode of regeneration" (sensu Veblen 1992). Large, dominant trees may represent even-aged, post-disturbance cohorts of western redcedar. Abundant western redcedar CWD may indicate senescence and recent mortality of an even-aged post-disturbance cohort. The low density of seedlings and saplings appears insufficient to replace canopy trees and maintain canopy dominance. Thus, the scarcity of regeneration indicates a population decline in absence of coarse-scale disturbance. How- 


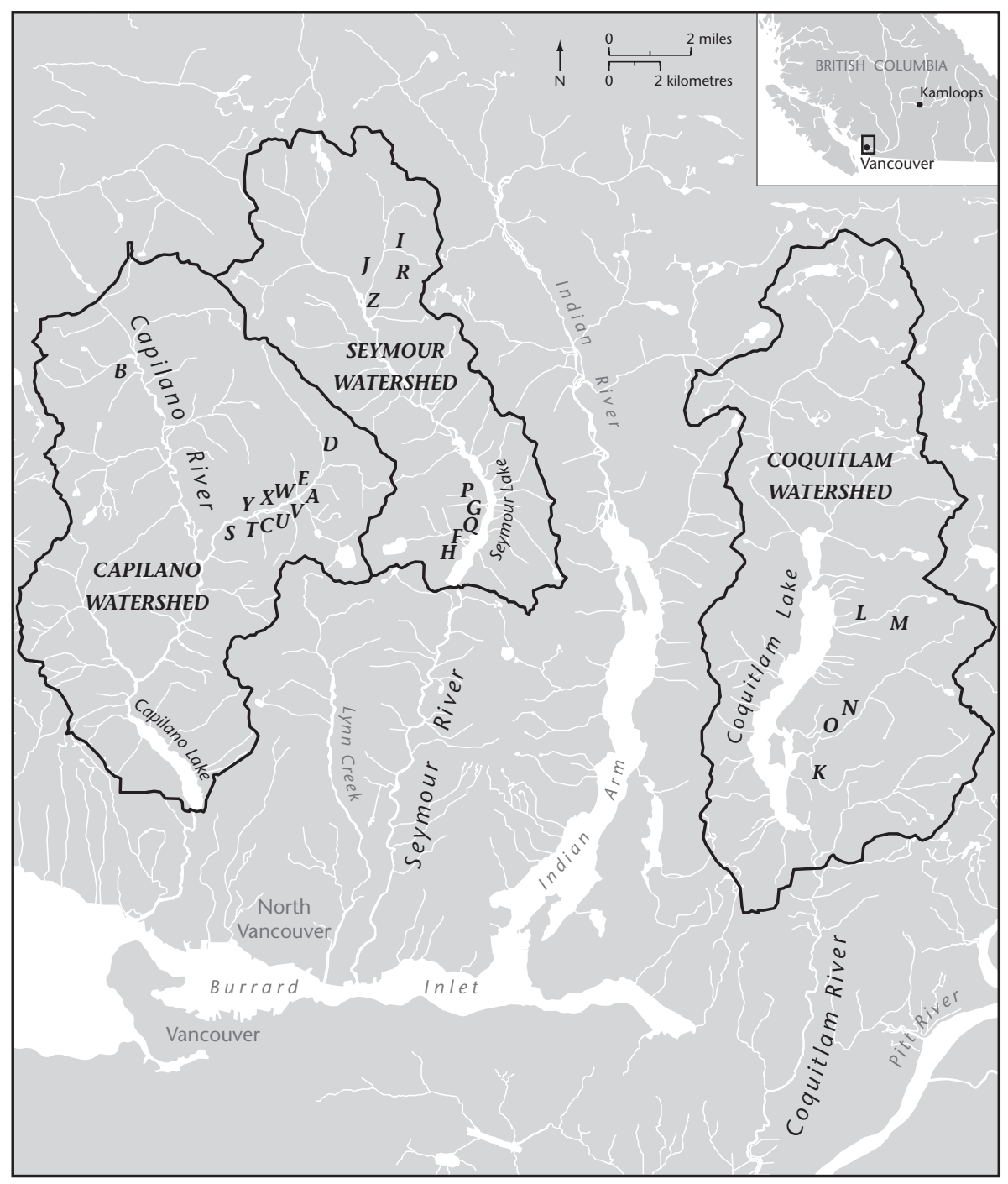

Fig. 1. The 26 study sites are located in the Capilano, Seymour and Coquitlan River watersheds, located north of Vancouver, British Columbia. Sites A to R were in clearcuts of former old-growth forests and sites $\mathrm{S}$ to $\mathrm{Z}$ were in extant old-growth forests.

ever, there are four assumptions implicit to this interpretation:

1. Tree size indicates age.

2. Populations establish as even-aged, post-disturbance cohorts.

3. Abundant CWD represents recent mortality.

4. Regeneration is insufficient to maintain canopy dominance.

The new ecological paradigm provides an alternative perspective and research framework from which to consider western redcedar population dynamics. This paper summarizes a series of studies in which I have used a dendroecological approach to document the influences of disturbance at three spatial scales - individuals, populations, and stands - in order to test these four assumptions.

\section{Study area}

This research was conducted in the Capilano, Coquitlam, and Seymour watersheds, an area of 57791 ha managed by the Greater Vancouver Water District (GVWD) for water supply to the greater Vancouver municipalities (Fig. 1). The study area was located within the Very Wet Maritime Coastal Western Hemlock (CWHvm) biogeoclimatic subzone, which delineates the influence of a very wet, cool mesothermal climate (Klinka et al. 1991). Mean annual temperature of the region is $8.2^{\circ} \mathrm{C}$, with a mean temperature in the warmest month of $16.0^{\circ} \mathrm{C}$ and in the cold- est month of $0.3^{\circ} \mathrm{C}$. Annual precipitation averages $2787 \mathrm{~mm}$, $752 \mathrm{~mm}$ of which falls during the summer growing season (Canadian Climate Program 1993). Soils are predominantly steepslope, coarse-skeletal, Ferro-Humic Podzols (Agriculture Canada Expert Committee on Soil Survey 1987) derived from colluvium and glacial till, and underlain by granite bedrock.

Stands in which western redcedar, western hemlock, Pacific silver fir and Douglas-fir compose the tree layer are prevalent on submontane sites in the watersheds where logging has not disturbed the forest cover. Most extant stands are considered old growth due to their structural complexity and the dominance of trees greater than 250 years of age (Acres International 1999). In these old-growth stands, Pacific silver fir grows to diameters of $100 \mathrm{~cm}$ at breast height, western hemlock to 120 $\mathrm{cm}$, and western redcedar and Douglas-fir to $250 \mathrm{~cm}$ (Daniels 1994). Life spans are 360 years for Pacific silver fir, 450 western hemlock and > 1000 for western redcedar and Douglas-fir (Daniels 1994).

Eight extant old-growth stands and 18 clearcuts of former old-growth stands were sampled to acquire data for the four studies summarized in this paper (Fig. 1). The clearcut sites range from 4 to 13 ha in area. According to forest inventory, each clearcut had been dominated by western redcedar $>250$ years old and 
included western hemlock and Pacific silver fir. Douglas-fir had been present at sites E, F, G, H, M, and N.

\section{Assumption 1: Tree Size Indicates Age}

Where large western redcedar and Douglas-fir co-dominate oldgrowth stands, western redcedar may be interpreted as a cohort that established concurrently with the shade-intolerant Douglas-fir following a catastrophic disturbance. Even in the absence of Douglas-fir, large western redcedar may be assumed to be among the oldest trees in old-growth stands given their long lifespan. Underlying these two interpretations is the assumption that tree size indicates age. The first of the four studies outlined in this paper was designed to test this assumption and to answer the question: Are dominant western redcedar the oldest trees in a stand?

\section{Methods}

To assess the relation between tree size and age, data were collected from 720 western redcedar (Daniels et al. 1995). Accurate age data are difficult to collect from western redcedar for several reasons. Trees with dbh exceeding about $160 \mathrm{~cm}$ are common but cannot be aged using increment cores because increment borers have a maximum length of $80 \mathrm{~cm}$ and are not long enough to sample a complete radius from the bark to the pith of the tree. Second, it is difficult to extract a core that includes the pith for large trees (dbh > approximately $100 \mathrm{~cm}$ ), especially when growth is asymmetrical. Third, it is not possible to extract a complete core from many western redcedar because of the high incidence of heartwood decay in this species. To overcome these limitations, age and size data were collected from 720 stumps in 15 clearcut sites (Daniels et al. 1995).

Fifteen clearcut sites, five in each of the three watersheds that comprise the study area, were located on mid-slope positions of various aspects at elevations from 400 to $825 \mathrm{~m}$ a.s.l. (A to $\mathrm{O}$ in Fig. 1). At each site, 48 western redcedar stumps with diameter $\geq 10 \mathrm{~cm}$ at stump height and with sound wood from the pith to the bark were located using random and systematic methods (Daniels et al. 1995). A minimum diameter of $10 \mathrm{~cm}$ was arbitrarily used to differentiate understorey seedlings and saplings from the tree layer that included subcanopy and canopy trees. Moreover, stumps with a diameter $<10 \mathrm{~cm}$ were difficult to locate in the cutovers as small trees were likely destroyed during harvesting. The diameter and height of stumps were measured and converted to diameter at breast height (dbh) using conversion tables (Demaerschalk and Omule 1978); all but four trees had a dbh $\geq 10 \mathrm{~cm}$. Field counts of annual rings were corrected for age at stump height to estimate tree ages (Daniels et al. 1995). Correction factors ranged from 17 to 33 years (Daniels et al. 1995).

\section{Results and discussion}

Western redcedar examined in this study included trees with dbh from 8 to $367 \mathrm{~cm}$. Ages ranged from 75 to 1051 years. For western redcedar comprising the tree layer of old-growth stands, larger trees were generally older than smaller trees (Fig. 2). The regression of age on size was statistically significant $\left(r^{2}=0.65, p<0.001\right)$; however, the standard error of estimated age was 109 years. The curvilinear relationship indicates that variance is not homogeneous over the range of diameters. Age predictions within the $95 \%$ confidence limits for trees with $\mathrm{dbh}$ of $100 \mathrm{~cm}$ are 150 to 600 years, and predictions for trees with dbh of $150 \mathrm{~cm}$ are 200 to 800 years.

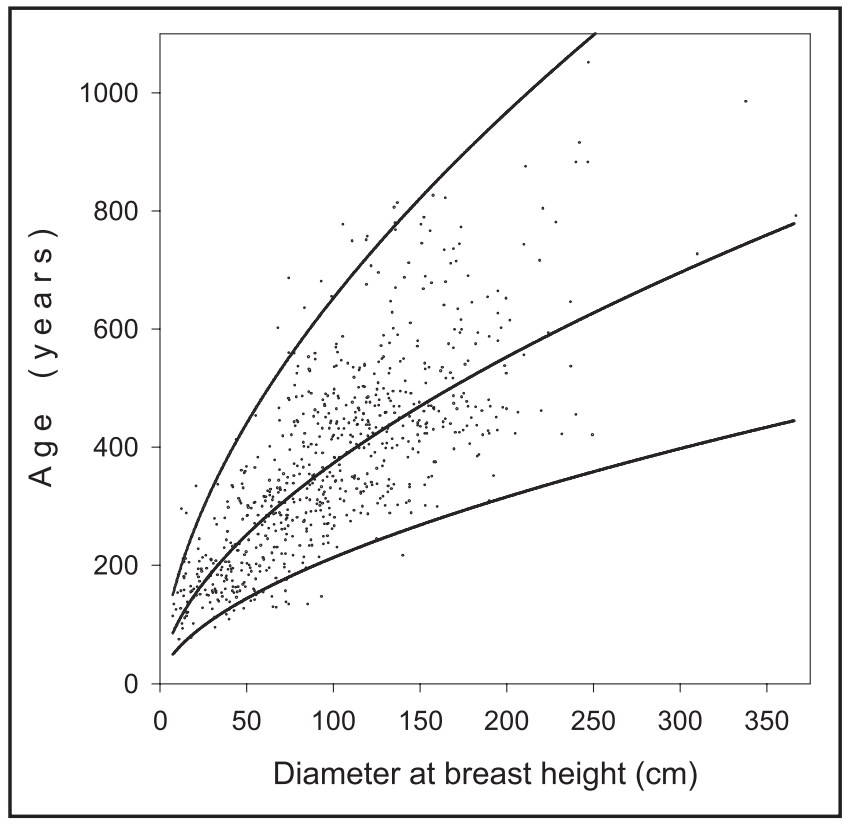

Fig. 2. Relationship between age and dbh for western redcedar with $\mathrm{dbh}>7.5 \mathrm{~cm}$. The middle curve marks the regression of age on $\mathrm{dbh}[\log 10($ age $)=1.435+0.568 \log 10(\mathrm{dbh})]$. Upper and lower curves are the regression line $+/-1.96$ SEE, including $95 \%$ of observations $(\mathrm{n}=720)$ (from Daniels et al. 1995)

At all diameters, size was neither accurate nor a precise indicator of the age of western redcedar trees. Large tree size may indicate relatively old trees, but the largest trees in a stand are not necessarily the oldest trees. At the population level, dominant trees do not necessarily represent a single age cohort. Size data are an inappropriate substitute for age data when interpreting the dynamics of these old-growth stands (Daniels et al. 1995).

\section{Assumption 2: Populations Establish as Even-aged, Post-Disturbance Cohorts}

The second study is a two-part study that addressed the question: What is the dominant mode of regeneration of western redcedar in old-growth forests? Populations that establish over relatively short periods of time following stand-devastating disturbance and sudden release of resources exhibit a "catastrophic regeneration mode" (Veblen 1992). Experimental studies and regeneration of western redcedar in managed stands show that regeneration of western redcedar can follow a catastrophic mode. For example, western redcedar germinates successfully on exposed mineral soil following fire (Klinka and Feller 1993). Preliminary data collected from a post-fire stand in the Seymour watershed that originated around 1895 showed that, following stand-level fires, western redcedar can form relatively even-aged cohorts (Daniels 1996). At this site, individual western redcedar were open-grown, meaning that radial growth pattern includes wide tree rings close to the pith and a geometric decline in ring width with age and size. Based on these contemporary observations, I predicted that if old-growth stands regenerated after catastrophic disturbances in past centuries, then western redcedar populations would include postdisturbance cohorts of old trees that exhibit an open-grown radial growth pattern. 


\section{Methods}

To test Assumption 2, age frequency distributions were prepared using the age data from the 15 study sites used to test Assumption 1 (Daniels et al. 1995). Age classes were 50 years with all trees $>850$ years included in the oldest class. The mean class frequency and its standard deviation were calculated for each distribution. Peak age classes were defined as those with a frequency greater than the mean frequency plus one standard deviation. Peak age classes were compared among study sites.

In the second part of this study, the radial growth patterns of western redcedar and Douglas-fir were assessed using supplementary data collected from sites $\mathrm{F}$ to $\mathrm{J}$ plus three additional cutovers in the Seymour watershed (Sites P, Q and R in Fig. 1) (Daniels 1996). Canopy tree composition, presence of charcoal, and age structures suggested that these eight sites had likely burned in the past. At sites F, G, and $\mathrm{H}$ the old-growth stands had been dominated by western redcedar and Douglas-fir prior to logging, and direct physical evidence of past fire at the sites included charcoal in the soil and root mounds of windthrown trees and burnt snags. Sites I and J were dominated by western redcedar but did not include Douglas-fir and showed no direct physical evidence of past fire. However, the age structures of sites $\mathrm{H}$ and $\mathrm{I}$ showed distinct age class peaks and included few trees older than 500 years (Fig. 3), possibly due to a stand-replacing disturbance at that time (Daniels et al. 1995).

Fifty-five western redcedar and 19 Douglas-fir stumps were located within the eight clearcut sites. Radial sections were cut from the surface of stumps and prepared following standard dendrochronological procedures (Stokes and Smiley 1968). To determine the calendar year of the pith, ring-width series were visually (Yamaguchi 1991) and statistically cross-dated using the program COFECHA (Holmes 1986). Pith dates were corrected for age at stump height to estimate tree ages. Correction factors for western redcedar ranged from 17 to 33 years (Daniels et al. 1995) and for Douglas-fir were 10 years (Agee 1993). The initial growth rates of trees (mm per year) were determined by counting the number of rings along a $5-\mathrm{cm}$ radius from the pith. The starting years of growth releases were noted. A release was defined as an increase in radial growth of $\geq 50 \%$ that was sustained for at least 10 years, so that a comparison of consecutive 10-year periods showed that mean ring width had increased by a factor of at least 1.5 (Lorimer and Frelich 1989).

\section{Results and discussion}

At the spatial scale of a patch on the landscape (e.g., the cutovers), western redcedar populations were uneven-aged (Fig. 3). The range in age at individual sites was at least 457 years and up to 891 years. All age distributions included peak age classes and most included multiple peaks or cohorts. Many peaks were concurrent in the 200 (e.g., $200=$ upper limit of the class from 151 to 200 years), 350,450 , and 500 classes, although the study sites were distributed throughout three different watersheds. At all sites there were at least three western redcedar of an age greater than the oldest cohort peak.

The age structures suggest disturbances of a range of magnitudes have influenced the stands. Peak age classes often indicate relatively severe disturbances that facilitated a pulse of regeneration (Veblen 1992). However, even at the sites dominated by individual cohorts, where stand-level disturbance most likely occurred, veteran western redcedar were present
(Fig. 3). Western redcedar has relatively thin bark that is very flammable, making it susceptible to fire rather than resistant to it (Agee 1993). The presence of veteran western redcedar suggests a need to carefully define a "catastrophic" disturbance in these forest systems and to better understand regional fire regimes. Also, climate variation influencing the success of western redcedar establishment or interactions between climate and fire cannot be eliminated as possible explanations for the peaks in the age histograms (Daniels et al. 1995).

The ring widths of the Douglas-fir were typical of trees establishing in large openings where competition is low and growth is relatively unrestricted. Initial radial growth averaged $3.68 \mathrm{~mm}$ per year (s.d. $=1.28, n=19)$ and ranged from 1.16 to $6.25 \mathrm{~mm}$ per year (Fig. 4). For 16 Douglas-fir, ring widths became progressively narrower as the tree grew, with no radial growth release. Two Douglas-fir released once during their 360-year lifespan and one tree released twice in 600 years.

In contrast with the Douglas-fir, the ring widths of 53 of 55 western redcedar showed suppressed growth at the time of establishment. Initial radial growth averaged $0.85 \mathrm{~mm}$ per year (s.d. $=0.43, n=55$, Fig. 4), which is significantly lower than the initial growth rate of Douglas-fir (Mann-Whitney rank sum test, $p<0.001)$. The initial growth of only two western redcedar was $>2 \mathrm{~mm}$ per year, one of which released once while the other showed no substantive, sustained radial growth release. Of the 53 western redcedar that were initially suppressed, four trees showed no release. The remaining 49 trees had released at least once, including two trees that had released four times during their 460- and 550-year life spans. Following release, high growth rates typically were sustained for one to several centuries.

The growth rates of western redcedar did not show open-growth ring-width patterns as predicted if the populations established following catastrophic disturbance. Initial growth patterns of western redcedar were similar at sites with and without physical evidence of fire. There was agreement between the age of Douglas-fir trees and ages and/or releases of western redcedar at sites $\mathrm{F}$ and $\mathrm{G}$; however, the western redcedar did not exhibit an open-grown ring-width pattern. The initial growth rates of western redcedar that established during peak age classes (Fig. 3) were not different from growth rates of western redcedar that established at other times (Mann-Whitney rank sum test, $p=0.54$ ).

I propose two possible interpretations of western redcedar growth rates. First, western redcedar may rarely produce wide initial growth rings even when it establishes in large openings. It is possible that my preliminary observation that western redcedar exhibits an open-grown ring-width pattern was not indicative of this species in the study area. To test this possibility, I have initiated an investigation of radial growth rates and allometric growth relations of relatively young ( $\leq 120$ years) trees within even-aged stands of mixed species composition, including western redcedar. Alternatively, slow initial radial growth may indicate that the trees were suppressed because they established beneath an existing canopy (Lorimer and Frelich 1989, Canham 1990, Payette et al. 1990, Orwig and Abrams 1994). Dominant western redcedar in the old-growth forest may have established after partial stand disturbances, in canopy gaps, or independently of disturbance.

In contrast to severe stand-level disturbances, fine-scale canopygap disturbances facilitate regeneration through time and result in a spread of ages among trees (Veblen 1992). Given 


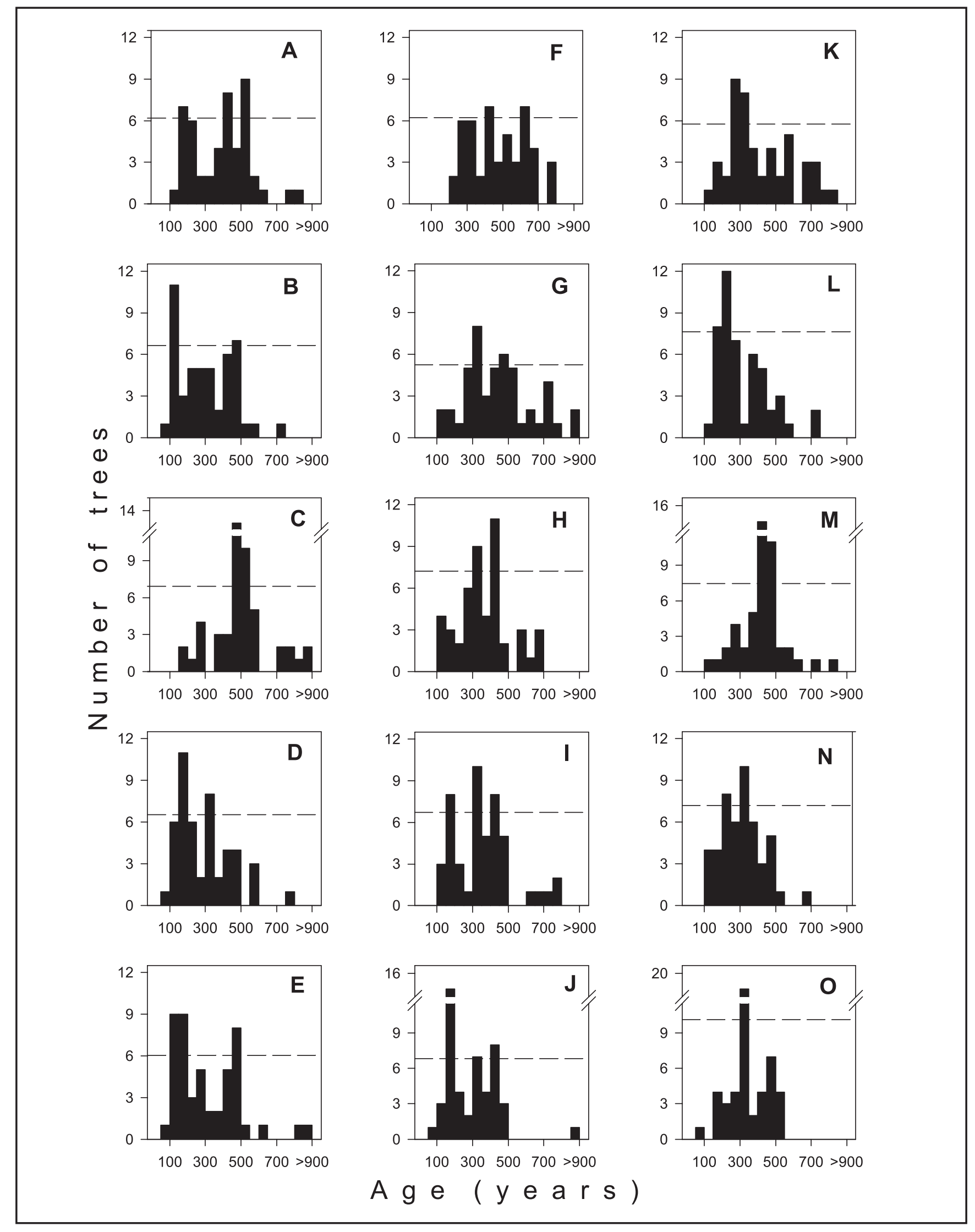

Fig. 3. Age frequency distributions of western redcedar in the tree layer $(\mathrm{dbh}>7.5 \mathrm{~cm})$ of sites A to O. The $\mathrm{x}$-axis labels show the upper limits of 50-year classes, except the oldest class which includes all trees with age $>850$ years. The broken lines mark the mean class frequencies +1 standard deviation of the mean; classes with frequencies above the line are "7 peak" classes (after Daniels et al.1995). 


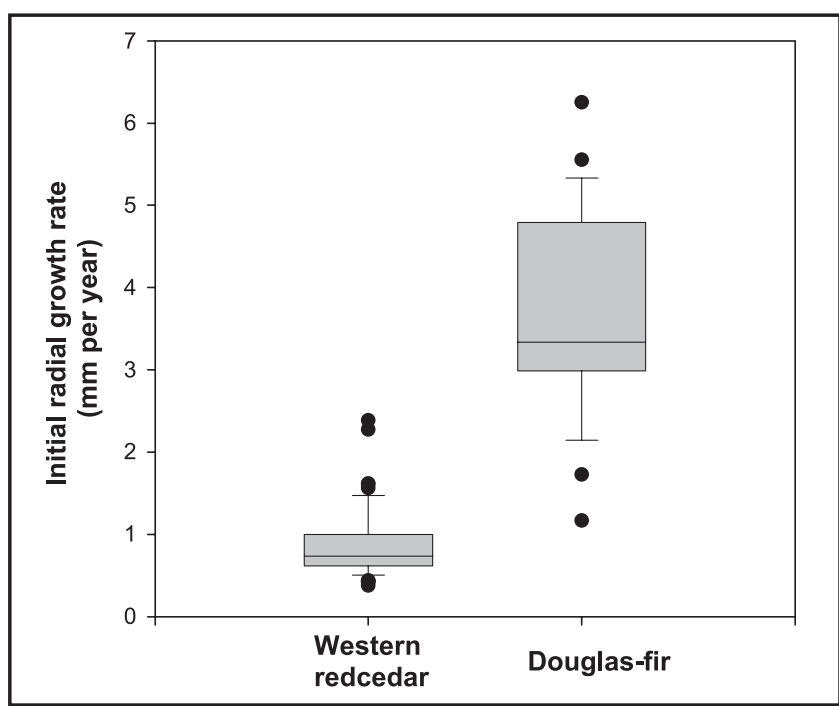

Fig. 4. Comparison of initial radial growth rates of western redcedar (left) and Douglas-fir (right). The median growth rates, represented by the horizontal lines inside the boxes, were significantly different (Mann-Whitney rank sum test, $\mathrm{p}<0.001$ ). The upper and lower limits of each box represent 25 th percentiles of age; the bars above and below each box represent 75 th percentiles; and, the dots represent the 90th percentiles.

the new ecological paradigm and understanding of disturbance in old-growth forests, it is now recognized that fine-scale disturbance is ubiquitous in coastal forests of British Columbia (Lertzman and Krebs 1991, Lertzman 1992, Beese and Sandford 1992, Lertzman et al. 1996). The uneven-age structures of western redcedar suggest that regeneration following catastrophic disturbance is not necessarily the dominant mode of regeneration in these forests. The age structures, combined with low initial radial growth rates, suggest that either gap-phase or continuous modes of regeneration of western redcedar may be more common than previously thought under the pretext of the traditional successional paradigm.

\section{Assumption 3: Abundant CWD Represents Recent Mortality}

The third study investigated snags and logs of western redcedar to determine whether this CWD resulted from recent mortality or had accumulated over time. Where live western redcedar dominate the canopy, CWD is often abundant. Logs in decay class 3 , with detached or missing bark but boles that are structurally intact (Thomas et al. 1979), are often particularly abundant (e.g., Keenan et al. 1993). Early reports of western redcedar wood decay in coastal forests suggested that $\operatorname{logs}$ in decay class 3 had been dead about 30 years and that by about 85 years, logs would advance to stage 4 of decay (Sollins et al. 1987). The same study indicated that logs of western redcedar, western hemlock, and Douglas-fir decay at comparable rates (Sollins et al. 1987). Given these similarities, one interpretation of the abundant CWD in decay class 3 is that it represents relatively high mortality of western redcedar during the last century. Specifically, it may represent the synchronous death of an overstorey cohort that established following a catastrophic disturbance and is now senescent and dying. Alternatively, it may represent mortality of western redcedar over several centuries and the accumulation of CWD due to very slow decomposition.

\section{Methods}

To differentiate recent mortality from accumulated mortality, Daniels et al. (1997) determined the year of death of 15 western redcedar logs and 17 snags that were at various stages of decay (Thomas et al. 1979). Using a range of historical reconstruction methods, including dendrochronological cross-dating of ring-width patterns and radiocarbon analysis of logs in advanced stages of decay, we determined the year of death of the trees and the "age" of the CWD (Daniels et al. 1997). The mean ages of the log and snag classes were compared by analysis of variance and the Tukey HSD method for multiple comparisons of the mean that accounted for unequal sample sizes (Norusis 1994).

\section{Results and discussion}

For snags in classes 4 to 6 , ages range from 41 to 276 years with overlap among all three classes (Fig. 5). Generally, the age of the logs increased with decay class, however the overlap in age of logs of classes 2 and 3 was sufficient that they could not be differentiated statistically (Fig. 5). Class 2 and 3 logs had been dead for 17 to 293 years; they ranged in diameter from 79 to $250 \mathrm{~cm}$ but remained relatively sound and will likely persist on the sites for decades to centuries. Class 4 logs were losing their structural integrity, having been dead at least 500 years (Fig. 5). The slow decay of western redcedar indicated by these results is consistent with its wood chemistry and resistance to decay (Barton and MacDonald 1971, Nault 1988, Kelsey and Harmon 1989, van der Kamp 1986). Recent results from a longterm experiment tracking CWD decay in coastal Oregon corroborate these observations (Harmon 1992).

The slow decay of western redcedar wood has resulted in an accumulation of logs and snags in old-growth stands over time. I concluded that the abundant CWD of western redcedar does not represent a pulse of recent mortality or synchronous death of an overstorey cohort. Nor does it represent a mortality rate that is disproportionate to the number of live trees in the canopy and subcanopy. Rather, tree deaths have occurred over a period of hundreds of years.

\section{Assumption 4: Regeneration Is Insufficient To Maintain Canopy Dominance}

Following the test of Assumption 2, I asserted that (1) the uneven-age structures and radial growth rates of dominant trees suggested that western redcedar is capable of successful regeneration in old-growth forests and (2) western redcedar may coexist with western hemlock and Pacific silver fir in late-successional forests, rather than being replaced by them. The fourth study considers mechanisms of western redcedar establishment and recruitment to the canopy as possible explanations for the relatively low density of western redcedar in the understorey of old-growth stands.

In coastal British Columbia, western redcedar, western hemlock, and Pacific silver fir tolerate shade, although none of the three species requires shade (Klinka et al. 1990, Carter and Klinka 1992). Theoretically, all three species can establish following both fine- and coarse-scale disturbances. Despite these similarities, the population size structures of the three species 


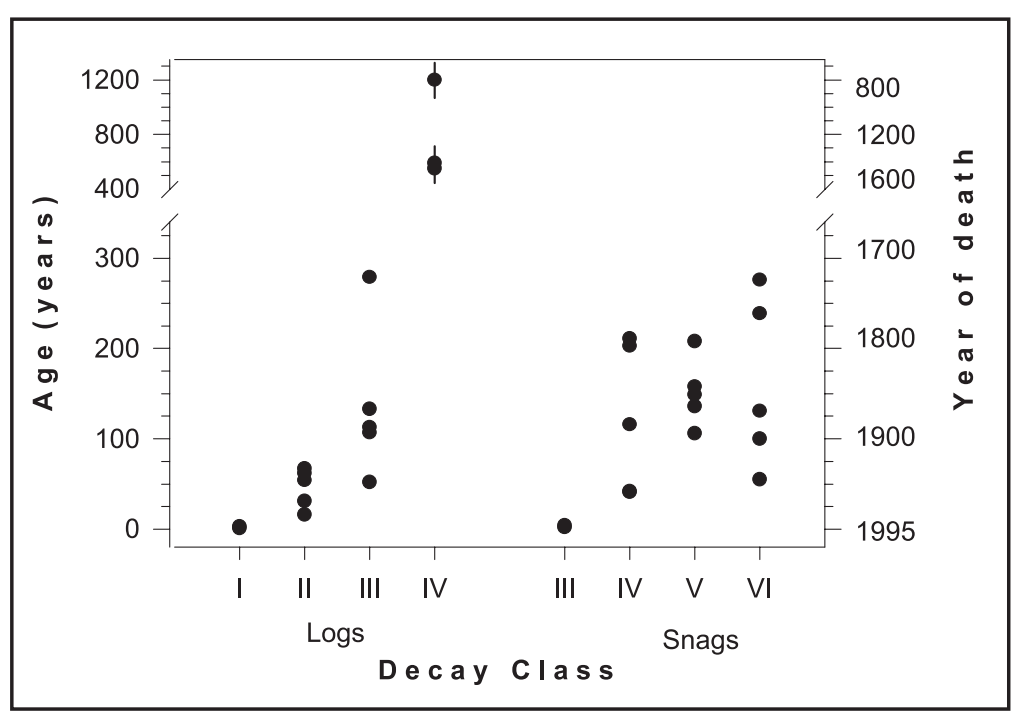

Fig. 5. Age and year of death for 15 logs and 17 snags of western redcedar. Age was calculated as 1995 minus the year of death. For logs in classes I to III, year of death was determined using dendrochronological methods including statistical crossdating. Class IV logs were aged by radiocarbon-dating; the vertical lines show $95 \%$ confidence intervals around the age estimates. The year of death of all snags determined by statistical crossdating (from Daniels et al.1997).

Table 1. Tree density by species and canopy stratum in eight study stands (0.49 ha) (after Daniels 1994). Mean values for the eight stands are followed by the standard deviation in parentheses

\begin{tabular}{|c|c|c|c|c|c|c|c|c|c|}
\hline \multirow{2}{*}{$\begin{array}{l}\text { Species } \\
\text { Canopy stratum }\end{array}$} & \multicolumn{9}{|c|}{ Study stand } \\
\hline & $S$ & $\mathrm{~T}$ & $\mathrm{U}$ & $\mathrm{V}$ & $\mathrm{W}$ & $\mathrm{X}$ & $\mathrm{Y}$ & $\mathrm{Z}$ & Mean (s.d.) \\
\hline \multicolumn{10}{|l|}{ Western redcedar } \\
\hline Seedlings & 59 & 249 & 179 & 148 & 638 & 808 & 1344 & 209 & $454(444)$ \\
\hline Saplings & 0 & 5 & 1 & 4 & 24 & 31 & 35 & 0 & $13(15)$ \\
\hline Subcanopy trees & 1 & 0 & 0 & 2 & 3 & 7 & 26 & 2 & $5(9)$ \\
\hline Canopy trees & 8 & 8 & 2 & 23 & 26 & 15 & 16 & 13 & $14(8)$ \\
\hline \multicolumn{10}{|l|}{ Western hemlock } \\
\hline Seedlings & 5782 & 10241 & 13132 & 5880 & 12495 & 7252 & 3553 & 10486 & $8603(3476)$ \\
\hline Saplings & 561 & 404 & 806 & 380 & 523 & 588 & 493 & 257 & $502(164)$ \\
\hline Subcanopy trees & 68 & 72 & 71 & 36 & 107 & 136 & 111 & 45 & $81(34)$ \\
\hline Canopy trees & 31 & 43 & 20 & 18 & 21 & 20 & 28 & 54 & $29(13)$ \\
\hline \multicolumn{10}{|l|}{ Pacific silver fir } \\
\hline Seedlings & 6909 & 2107 & 5929 & 4018 & 147 & 147 & 98 & 5194 & $3069(2807)$ \\
\hline Saplings & 40 & 338 & 383 & 784 & 68 & 7 & 16 & 637 & $284(303)$ \\
\hline Subcanopy trees & 2 & 21 & 170 & 61 & 17 & 6 & 12 & 109 & $50(60)$ \\
\hline
\end{tabular}

differ substantially (Keenan 1993, Daniels 1994). The abundance of western hemlock and Pacific silver fir in the understorey of old-growth stands suggests that opportunities for regeneration of these two species are not limited. In contrast, the intermittent establishment of western redcedar at fine spatial scales (Gregory 1957, Keenan 1993, Daniels 1994) suggests that opportunities for its successful regeneration may be limited either spatially or temporally. In this last study, I have used stand structure analysis and historical reconstruction techniques to examine regeneration niches and recruitment modes as possible mechanisms of co-existence of western redcedar, western hemlock, and Pacific silver fir in old-growth stands.

\section{Methods}

In 1992, I established eight plots in western redcedar-dominated old-growth stands (Sites S to Z in Fig. 1; Daniels 1994). The plots measured $70 \times 70 \mathrm{~m}$ (0.49 ha). In each plot, I recorded the species, location, dbh $(\mathrm{cm})$, height $(\mathrm{m})$, and canopy position (subcanopy versus canopy) of all trees $(\mathrm{dbh}>10 \mathrm{~cm}$ ). Seedlings (height $\leq 130 \mathrm{~cm}$ ) and saplings (height $>13 \mathrm{~cm}, \mathrm{dbh}$ $\leq 10 \mathrm{~cm}$ ) of western redcedar were censused and their location, rooting substrate (CWD, exposed mineral soil, or undisturbed forest floor), and height were recorded. The same attributes were measured for western hemlock and Pacific silver fir seedlings and saplings within systematically located $2 \times 2 \mathrm{~m}$ and $10 \times 10 \mathrm{~m}$ quadrats, respectively. Morisita's index of dispersion $\left(I_{d}\right)$ was used to test the spatial distributions of western redcedar seedlings and saplings within nested quadrats ranging from 16 to $576 \mathrm{~m}^{2}$. It was calculated for western hemlock and Pacific silver fir seedlings in 4- $\mathrm{m}^{2}$ quadrats and saplings in $100-\mathrm{m}^{2}$ quadrats. Within each plot, ground cover was estimated along four 70$\mathrm{m}$ line transects. The extent along each line of CWD, exposed mineral soil, undisturbed forest floor, water and bedrock was measured and average percent cover of each type was calculated.

Daniels and Klinka (1996) conducted a dendroecological reconstruction of historic canopy gaps within 0.23 -ha subplots nested within plots $\mathrm{V}$ and $\mathrm{Z}$. Increment cores were extracted from the base (about 20-50 cm above ground) of all trees with $\mathrm{dbh}>10 \mathrm{~cm}$. Ring-width series were visually cross-dated (Yamaguchi 1991). The starting year of growth releases were noted. As in the test of Assumption 2, a release was defined as an increase in radial growth of $\geq 50 \%$ that was sustained for at least 10 years, so that a comparison of consecutive 10-year periods showed that mean ring width had increased by a factor of at least 1.5 (Lorimer and Frelich 1989). Historic gaps were delineated from the release dates and tree growth histories were compared for trees stratified by species and canopy position (Daniels and Klinka 1996). 

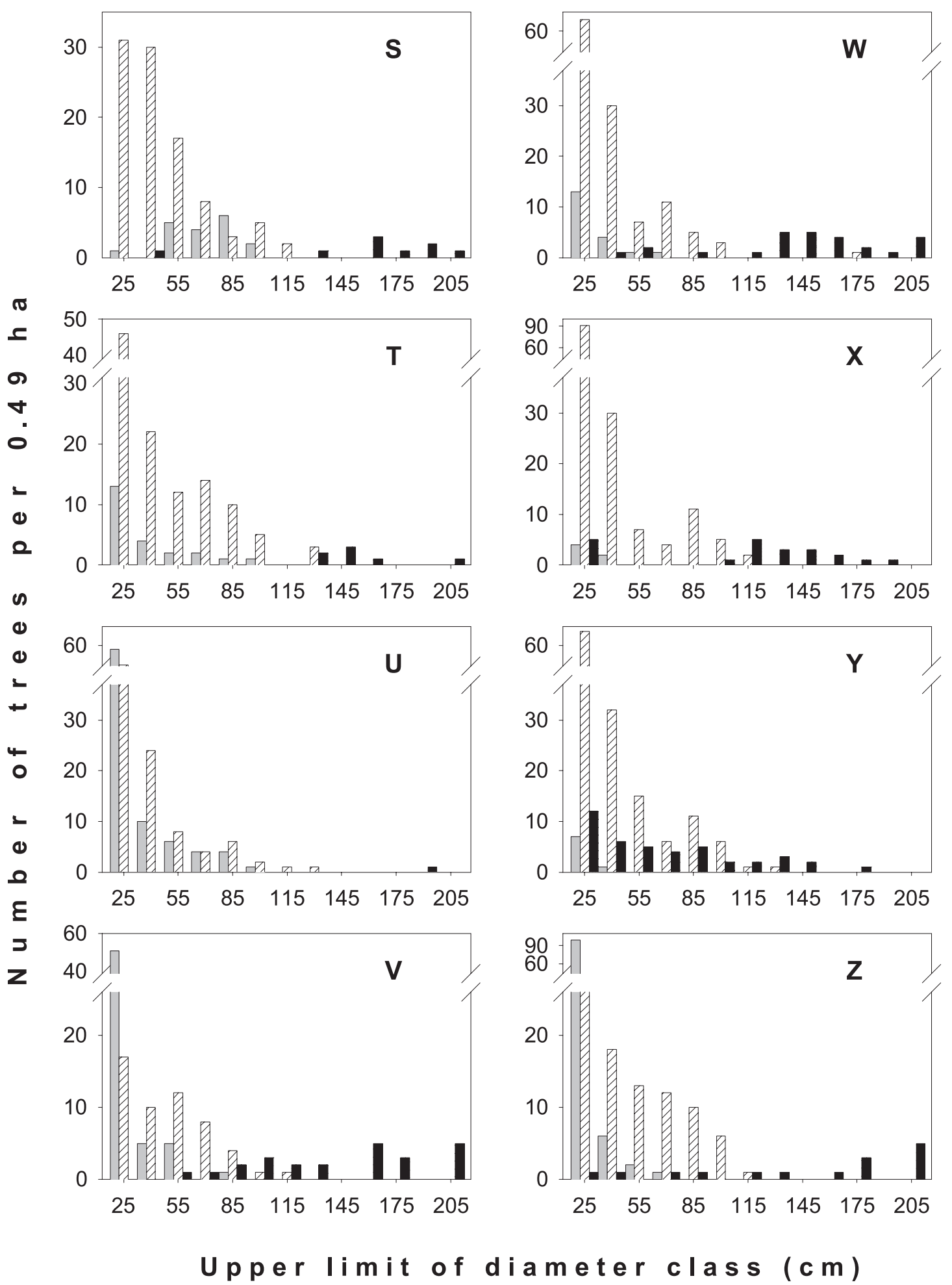

Fig. 6. Diameter distributions of subcanopy and canopy trees $(\mathrm{dbh}>10 \mathrm{~cm})$ in eight study stands. Tree species are western redcedar (black), western hemlock (hatched) and Pacific silver fir (grey). Sites S to V were on north-facing slopes (left column); sites W to Z faced south (right column). Trees are grouped in $15 \mathrm{~cm}$ diameter classes from $10 \mathrm{~cm}$ (after Daniels 1994).

For western redcedar, complete ring-width series were sampled for only seven of 21 trees in plots $\mathrm{V}$ and $\mathrm{Z}$ because of the low density of subcanopy trees, the large size of canopy trees, and the high incidence of heartwood decay in trees of all sizes (Daniels and Klinka 1996). Thus, the ring-width series from the 55 western redcedar sampled in eight clearcuts in the 
Seymour watershed (See "Test of Assumption 2") supplemented the data and increased sample size. For these 55 trees, dbh ranged from 96 to $238 \mathrm{~cm}$; thus, I assumed they had occupied the canopy prior to cutting.

\section{Results and discussion}

If you assume that many seedlings and saplings are required to replace a few canopy trees or that the diameter distribution must form a "reverse-J" shape or "balanced" distribution, then it is logical to classify western redcedar populations as declining and western hemlock and Pacific silver fir as increasing in many stands (Table 1 and Fig. 6). However, this interpretation implicitly assumes that rates of seedling and sapling establishment, survival, mortality, and recruitment to successive canopy strata are equivalent between species. Instead, differences in the life histories, including regeneration niche and mode of recruitment, may explain contrasting population structures of western redcedar, western hemlock, and Pacific silver fir (Turner and Franz 1985, Keenan 1993, Daniels 1994).

Seedlings and saplings western redcedar, western hemlock, and Pacific silver fir were significantly aggregated at fine spatial scales ( $p<0.001$ for all quadrats $\leq 256 \mathrm{~m}^{2}$; Daniels 1994). Common rooting substrates among the three species indicate spatial overlap of their regeneration niches (Table 2; Daniels 1994). Decaying wood and mineral soil, substrates created by gap-phase disturbances, were important substrates for seedlings and saplings, respectively. More than $70 \%$ of seedlings and saplings of western hemlock and western redcedar were growing on decaying wood, although CWD accounted for only $39 \%$ of ground cover within plots, on average. Pacific silver fir also established on decaying wood but was most common on undisturbed forest floor. For all three species, the proportion of saplings growing on mineral soil was greater than the proportion of seedlings on mineral soil. Assuming similar ingress of seedlings over time, these results suggest seedlings rooted in mineral soil grow rapidly and/or have high rates of successful recruitment to the sapling stratum relative to seedlings growing on decaying wood and the forest floor. Given the overlap in substrate use by the three species, spatial partitioning of the regeneration niche does not appear to explain the differences in population structures (Daniels 1994). Additional research is needed to clarify the influence of microsite characteristics on seedling establishment of the three study species in these forests.

Opportunities for tree regeneration in old-growth forests may be partitioned temporally via different rates of recruitment between canopy strata (e.g., understorey to subcanopy to canopy strata). The trends in Table 3 suggest that the three study species may respond differently to canopy gaps (Daniels and Klinka 1996) or exhibit with different "modes of recruitment" (Canham 1989). Pacific silver fir and western hemlock appear to depend on gaps to recruit to the canopy. Although individual Pacific silver fir were up to $60 \mathrm{~m}$ tall, this species was rare in the canopy (Daniels 1994). Most Pacific silver fir trees were suppressed in the subcanopy with ages up to 360 years. Sixty trees had released one to four times but had not recruited from the subcanopy to the canopy (Daniels and Klinka 1996). Western hemlock trees were up to 423 years old and $55 \mathrm{~m}$ tall (Daniels 1994). Western hemlock populations included suppressed subcanopy trees and many canopy trees that had recruited in gaps. Nine suppressed trees remained in the subcanopy; another 32 trees had released but not recruited to the canopy. More than half of
Table 2. Distribution of regeneration of western redcedar, western hemlock, and Pacific silver fir on different substrates. The mean percent cover followed by standard deviation in parentheses is provided for each substrate type ( $n=8$ study sites)

\begin{tabular}{lccc}
\hline \multirow{2}{*}{$\begin{array}{l}\text { Species } \\
\text { Size class }\end{array}$} & \multicolumn{3}{c}{ Percentage of individuals by substrate type } \\
\cline { 2 - 4 } & Forest floor & Decaying wood & Mineral soil \\
\hline $\begin{array}{l}\text { Western redcedar } \\
\text { Seedlings }(n=1840)\end{array}$ & 12 & $39(10)$ & $6(4)$ \\
$\begin{array}{l}\text { Saplings }(n=921) \\
\text { Western hemlock }\end{array}$ & 16 & 79 & 9 \\
Seedlings $(n=1483)$ & 8 & 70 & 14 \\
Saplings $(n=1303)$ & 12 & 90 & 2 \\
Pacific silver fir & & 81 & 7 \\
Seedlings $(n=490)$ & 61 & 38 & 1 \\
Saplings $(n=883)$ & 50 & 44 & 6 \\
\hline
\end{tabular}

Table 3. Number of releases in the ring-width series of trees $(\mathrm{dbh}>$ $10 \mathrm{~cm}$ ) stratified by species and canopy position

\begin{tabular}{lccc}
\hline Species & $\begin{array}{c}\text { Number of } \\
\text { releases }\end{array}$ & Subcanopy & Canopy \\
\hline Pacific silver fir $^{1}$ & $0-1$ & 53 & 2 \\
$(n=88)$ & $\geq 2$ & 32 & 1 \\
Western hemlock $^{1}$ & $0-1$ & 30 & 10 \\
$(n=64)$ & $\geq 2$ & 11 & 13 \\
Western redcedar $^{1}$ & $0-1$ & 1 & 5 \\
$(n=7)$ & $\geq 2$ & 1 & 0 \\
Western redcedar $^{2}$ & $0-1$ & n.a. & 28 \\
$(n=55)$ & $\geq 2$ & n.a. & 27
\end{tabular}

${ }^{1}$ Data from Daniels and Klinka (1996) included all trees with dbh $\geq 10 \mathrm{~cm}$ ${ }^{2}$ Data from Daniels (1996) were from stumps with dbh of 96 to $238 \mathrm{~cm}$ and were assumed to be upper canopy trees before cutting. Smaller stumps were not sampled in this study.

trees in the canopy had released two to four times indicating recruitment facilitated by multiple gap events (Daniels and Klinka 1996).

Only two western redcedar were located in the subcanopy of plots $\mathrm{V}$ and $\mathrm{X}$ where canopy gaps were reconstructed (Daniels and Klinka 1996). One subcanopy tree was 166 years old and had released once; the other tree was 224 years and had released twice. The age of the 60 canopy trees ranged from 199 to 959 years. Eight canopy trees had never released but had grown to diameters of 110 to $200 \mathrm{~cm} ; 25$ trees were initially suppressed and had released only once; 27 trees had released two to four times.

The radial growth pattern of western redcedar may indicate that it does not depend on gaps to recruit from the subcanopy to the canopy. Its mode of recruitment may be slow, consistent growth of subcanopy trees that rarely respond to gaps. Over their lifetime, such trees are likely influenced by gaps and release, although they are not dependent on gaps to recruit (Canham 1988, 1989; Schupp et al. 1989). Three observations support this interpretation. First, under low light conditions western redcedar maintains apical dominance and height increment but western hemlock and Pacific silver do not (Carter and Klinka 1992, Klinka et al. 1992). Second, the average delay between establishment and the first release for western redcedar was 111 years (s.d. $=50, n=50$ ), when trees average about $20 \mathrm{~cm}$ in diameter (s.d. $21 \mathrm{~cm}, n=50$ ). The consistent, sustained release of trees of relatively small diameter suggests a critical size threshold beyond which the trees successfully recruit to the canopy. The release and recruitment of western redcedar may depend 
on crown exposure to light at critical heights in the canopy, rather than the chance occurrence of a canopy gap. Third, releases of western redcedar are infrequent relative to western hemlock and Pacific silver fir, especially given the long lifespan of western redcedar that affords more opportunity for multiple periods of suppression and release (Table 3 ).

Differences in mode of recruitment between western redcedar, western hemlock, and Pacific silver fir may explain the differences in their population structures. Western hemlock and Pacific silver fir appear to depend on canopy gaps, thus opportunities to recruit to the canopy are limited by the availability of canopy gaps. Abundant regeneration in the understorey provides a "seedling bank" able to respond rapidly and exploit resources available in a gap. This "gap-dependent" model predicts variable radial growth with periodic suppressions and releases of individual trees and relatively high rates of both recruitment and mortality between successive canopy strata for western hemlock and Pacific silver fir populations. In contrast, if western redcedar is "gap-independent," then it does not depend on gaps to recruit to the canopy and opportunities to recruit are not limited by the availability of gaps. This model predicts slow radial growth until trees reach a critical size that increases their exposure to light allowing them to recruit into the canopy during a single, sustained release. At the population level, the rate of mortality of saplings and understorey trees would be relatively low and it would not require a seedling bank.

I have undertaken two approaches to test the hypothesis that recruitment of western hemlock and Pacific silver fir depends on canopy gaps, while western redcedar recruitment is independent of gaps. The first approach combines population modelling with monitoring of permanent plots to examine rates of population change. Life-cycle models based on size- and age-class data estimated rates of ingress to the understorey, recruitment to the subcanopy and canopy tree strata, and mortality from all three strata (Daniels and Tait 1996). The modelling results concur with the inferences made from tree population structures. For example, low ingress of western redcedar is followed by negligible mortality in the subcanopy and high recruitment success to the canopy (Table 4). However, both the modelling results and population structure interpretations are restricted by the assumptions and limitations inherent to static demographic data (Veblen 1992). Thus, these estimated rates of population change provide the basis for interspecific comparisons to be tested with permanent plot data. Since 1992, I have monitored tree recruitment and mortality in seven research plots (sites T to Z in Fig. 1). Re-sampling of 1318 tagged trees in 1997 revealed more tree deaths and recruitment of western hemlock and Pacific silver fir relative to western redcedar, but rates of population change were slow (Daniels and Daniels 1997), as noted in similar long-term studies (Franklin and DeBell 1988, Spies et al. 1990, Edmonds et al. 1993). The permanent plots will be re-measured in 2002 .

The second approach to test for differences in modes of recruitment of western redcedar, western hemlock, and Pacific silver fir is a replicated dendroecological analysis of old-growth stands. This study includes an intensive analysis of species-specific growth responses to canopy gaps, expanding on the research of Daniels and Klinka (1996).

\section{Conclusions and Management Implications}

Although western redcedar can regenerate following catastrophic disturbances such as fire or logging, stand-level disturbances are not necessary to sustain redcedar in old-growth forests. The four assumptions underlying the catastrophic paradigm of redcedar regeneration in old-growth stands were not supported by age and growth data derived from dendroecological analyses. Below are my conclusions drawn from the tests of four assumptions about western redcedar dynamics:

Assumption 1. Tree size indicates age. Tree size proved to be a poor indicator of age. The largest trees in a stand are not necessarily the oldest trees and dominant trees do not necessarily represent a single age cohort.

Assumption 2. Populations establish as even-aged, post-disturbance cohorts. Uneven age structures and low initial growth rates suggest that regeneration following catastrophic disturbance is not necessarily the dominant mode of regeneration of western redcedar. Rather, regeneration following fine-scale, gapphase disturbances is more common than previously thought. Assumption 3. Abundant CWD represents recent mortality. Western redcedar snags and logs have accumulated over several centuries. This CWD is persistent and represents centuries of accumulated tree mortality rather than recent tree deaths.

Assumption 4. Regeneration is insufficient to maintain canopy dominance. Preliminary evidence suggests that western redcedar recruitment from the subcanopy to the canopy may be independent of gaps. Thus, western redcedar populations may be maintained in old-growth forests despite low density of seedlings and saplings in the understorey. In contrast, western hemlock and Pacific silver fir depend on canopy gaps to recruit to the canopy and thus require an abundance of seedlings, saplings, and subcanopy trees that are able to respond rapidly and exploit resources that become available in a gap.

Returning to the contemporary view of old growth, it is evident that gap dynamics prevail in western redcedar-dominated old-growth forests. Establishment of western redcedar seedlings on CWD and exposed mineral soil follows a gap-phase mode, although recruitment of trees from the subcanopy to the canopy appears continuous. Establishment and recruitment of western hemlock and Pacific silver fir are associated with canopy gaps. In this model of stand dynamics, fine-scale canopy gaps in old-growth forests are essential to sustain coexisting populations of western redcedar, western hemlock, and Pacific silver fir. This contemporary view distinctly contrasts with the traditional view of forest succession in which western redcedar is replaced by western hemlock and Pacific silver, under the dominant influence of regional climate and in the absence of disturbance.

The traditional and contemporary interpretations of oldgrowth forest dynamics imply different strategies for managing western redcedar. According to the traditional paradigm, catastrophic, stand-level disturbances are needed to establish dominant populations of western redcedar. Thus, harvesting at relatively coarse scales was perceived as necessary to manage and sustain the species. In contrast, this study showed that western redcedar successfully regenerates in association with disturbances of a range of spatio-temporal scales, including fine-scale canopy gaps. These results provide an ecological precedent for use of a range of silvicultural systems, including clearcuts through single-tree harvesting and protection forest (sensu Klinka et al. 1990), when managing western redcedar in coastal British Columbia.

Ecosystem management aims to conserve biodiversity and maintain ecosystem function while sustaining renewable resources (BCMoF 1995, Christensen et al. 1996, Lertzman et al. 1997) 
Table 4. Estimated annual rates of tree population change in old-growth stands dominated by western redcedar. Estimates were derived from speciesspecific life-cycle models developed using size and age data from the study area (after Daniels and Tait 1996)

\begin{tabular}{|c|c|c|c|c|c|c|}
\hline \multirow[b]{2}{*}{ Species } & \multirow[b]{2}{*}{ Ingress } & \multicolumn{5}{|c|}{ Annual rates of change } \\
\hline & & $\begin{array}{c}\text { Understorey } \\
\text { mortality }\end{array}$ & $\begin{array}{l}\text { Recruitment } \\
\text { to subcanopy }\end{array}$ & $\begin{array}{c}\text { Subcanopy } \\
\text { mortality }\end{array}$ & $\begin{array}{l}\text { Recruitment } \\
\text { to canopy }\end{array}$ & $\begin{array}{c}\text { Canopy } \\
\text { mortality }\end{array}$ \\
\hline Western redcedar & 49 & $4.26 \times 10^{-2}$ & $2.03 \times 10^{-4}$ & 0 & $5.87 \times 10^{-3}$ & $4.09 \times 10^{-3}$ \\
\hline Western hemlock & 255 & $3.59 \times 10^{-2}$ & $2.05 \times 10^{-4}$ & $5.36 \times 10^{-3}$ & $2.58 \times 10^{-3}$ & $9.04 \times 10^{-3}$ \\
\hline Pacific silver fir & 84 & $2.04 \times 10^{-2}$ & $1.26 \times 10^{-4}$ & $9.78 \times 10^{-3}$ & $0.81 \times 10^{-3}$ & $9.57 \times 10^{-3}$ \\
\hline
\end{tabular}

To achieve these goals, patterns of natural variation can be used to guide management activities (Lertzman et al. 1997, Landers et al. 1999). It is now recognized that traditional even-aged approaches to forest management substantially alter the structural characteristics of coastal old-growth forests of British Columbia and these changes have significant consequences for the forest biota (Bunnell et al. 1999, Drever 2000). Variable retention (VR) silviculture aims to maintain trees of a range of ages and structural diversity within stands and distributes cutting over periods of decades to centuries, emulating both partial stand disturbances and canopy gap disturbance regimes more closely than clearcut harvesting does (Franklin et al. 1997, Dunsworth and Beese 2000, Beese et al. 2003). VR has been proposed as one method toward a sustainable approach for timber management of coastal old-growth forests (Lertzman et al. 1996, 1997; Scientific Panel 1995; Pojar et al. 1999; Drever 2000).

From an ecological perspective, successful VR needs to maintain structural attributes in the managed forest while sustaining a diverse species composition. To achieve these goals requires a comprehensive understanding of the regeneration dynamics of individual species in the context of the multiple disturbance regimes, including harvesting, that influence oldgrowth forests. Such knowledge provides both ecologically based guidelines for management decisions as well as criteria for evaluating and monitoring outcomes and success. As this study has illustrated, many questions remain unanswered about the dynamics, processes, and mechanisms that allow tree populations to be sustained and to coexist in old-growth forests. The contemporary ecological paradigm provides a framework for addressing these types of questions. The answers are needed to guide management decisions and to ensure future successful management and protection of the coastal old-growth forests of British Columbia.

\section{Acknowledgements}

I thank the Greater Vancouver Regional District for permission to conduct this research. Financial support was provided by the BC Ministry of Forests, GVRD Watershed Management, and the Science Council of BC. I thank many friends for assistance in the field and lab. Special thanks to K. Klinka for the many discussions that preceded these studies, and to K. Lertzman, A. MacKinnon, W. Beese, S. Gaultier and one anonymous reviewer for helpful comments on this manuscript.

\section{References}

Acres International. 1999. Annex to the Analysis Report Watershed Management Plan \#5, Volume I. GVRD Watershed Ecological Inventory Program, Burnaby, B.C.

Agee, J.K. 1993. Fire ecology of Pacific northwest forests. Island Press, Washington, D.C., USA. 493 p.

Agriculture Canada Expert Committee on Soils. 1987. The Canadian system of soil classification. 2nd edition Agriculture Canada Publication 1646. $164 \mathrm{p}$
Barton, G.M. and B.F. MacDonald. 1971. The chemistry and utilization of western redcedar. Department of Fisheries and Forestry, Canadian Forest Service. Ottawa, Ontario. Publication no. 1023.

Beese, W.J., B.G. Dunsworth, K. Zielke and B. Bancroft. 2003. Maintaining attributes of old-growth forests in coastal B.C. through variable retention. The Forestry Chronicle 79(3): 570-578.

Beese, W.J. and H.S. Sandford. 1992. Age of old-growth forests on Vancouver Island. British Columbia Ministry of Forests Contract Report \#98444. MacMillan Bloedel Ltd., Woodlands Services Division. Nanaimo, B.C. 19 p.

British Columbia Ministry of Forests. 1995. Biodiversity guidebook, forest practices code of British Columbia. Victoria, B.C. 99 p.

Bunnell, F.L., L.L. Kremsater and E. Wind. 1999. Managing to sustain vertebrate richness in forests of the Pacific Northwest: relationships within stands. Environmental Reviews 7: 97-146.

Canadian Climate Program. 1993. Canadian climate normals 1961-1990, British Columbia. Ministry of Supplies and Services of Canada. Ottawa, Ontario. 134 p.

Canham, C.D. 1988. Growth and canopy architecture of shade-tolerant trees: response to canopy gaps. Ecology 69: 786-795.

Canham, C.D. 1989. Different responses to gaps among shade-tolerant tree species. Ecology 70: 548-550.

Canham, C.D. 1990. Suppression and release during canopy recruitment in Fagus grandifolia. Bulletin of the Torrey Botanical Club 117: 1-7.

Carter, R.E. and K. Klinka. 1992. Variation in shade tolerance of Douglas-fir, western hemlock, and western redcedar in coastal British Columbia. Forest Ecology and Management 55: 87-105.

Christensen, H.L. (Chair), A.M. Bartuska, J.H. Brown, S. Carpenter, C. D'Antonio, R. Francis, J.F. Franklin, J.A. MacMahon, R.F. Noss, D.J. Parsons, C.H. Peterson, M.G. Turner and R.G. Woodmansee. 1996. The report of the Ecological Society of America committee on the scientific basis for ecosystem management. Ecological Applications 6: 665-691.

Daniels, L.D. 1994. Structure and dynamics of Thuja plicata dominated old-growth stands near Vancouver, British Columbia. M.Sc. Thesis. Department of Forest Sciences, University of British Columbia. 97 p.

Daniels, L.D. 1996. Fire history of three areas in the Seymour watershed interpreted from tree rings. Report to B.A. Blackwell and Associates, Acres International Ltd., and the Greater Vancouver Water District. Vancouver, B.C. 44 p.

Daniels, L.D. and S.J. Daniels. 1997. Submontane old-growth forest permanent plot re-measurement: 1992-97. Report to Acres International Ltd., and the Greater Vancouver Water District. Vancouver, B.C. 4 p.

Daniels, L.D., J. Dobry, M.C. Feller and K. Klinka. 1997. Determining year of death of logs and snags of Thuja plicata in southwestern coastal British Columbia. Canadian Journal of Forest Research 27: 1132-1141.

Daniels, L.D. and K. Klinka. 1996. The dynamics of old-growth ThujaTsuga forests near Vancouver, British Columbia. In J.S. Dean, D.M. Meko and T.W. Swetnam (eds.). Tree rings, environment and humanity, conference of the Tree-Ring Society. pp. 379-393. May 1994. Tucson, Arizona. 
Daniels, L.D., P.L. Marshall, R.E. Carter and K. Klinka. 1995. Age structure of Thuja plicata in the tree layer of old-growth stands near Vancouver, British Columbia. Northwest Science 69: 175-183. Daniels, L.D. and D. Tait. 1996. Old-growth models for the Vancouver watersheds, British Columbia. Report to Acres International Ltd., and the Greater Vancouver Water District. Vancouver, B.C. 48 p.

Demaerschalk, J.P. and S.A.Y. Omule. 1978. Stump and breast height diameter tables for the British Columbia merchantable trees species. Faculty of Forestry, University of British Columbia. Vancouver, B.C.

Drever, R. 2000. A cut above: ecological principles for sustainable forestry on British Columbia's coast. The David Suzuki Foundation, Vancouver, B.C. 66 p.

Dunsworth, B.G. and W.J. Beese. 2000. British Columbia, Canada: new approaches in managing temperate rainforests. In M. Price, T. Kohler and T. Wachs (eds.). Montane forests and sustainable development. pp 23-24. Mountain Agenda, Centre for Development and Environment, Institute of Geography, University of Berne, Switzerland.

Edmonds, R.L., T.B. Thomas and K.P. Maybury. 1993. Tree population dynamics, growth and mortality in old-growth forest in the western Olympic Mountains, Washington. Canadian Journal of Forest Research 23: 512-519.

Franklin, J.F., D.R. Berg, D.A. Thornburgh and J.C. Tappeiner. 1997. Alternative silvicultural approaches to timber harvesting: variable retention harvest systems. In K.A. Kohn and J.F. Franklin (eds.). Creating a forestry for the $21^{\text {st }}$ century: the science of ecosystem management. pp 111-139.Island Press, Washington, D.C., USA.

Franklin, J.F. and D.S. DeBell. 1988. Thirty-six years of tree population change in an old-growth Pseudotsuga-Tsuga forest. Canadian Journal of Forest Research 18: 633-639.

Franklin, J.F. and C.T. Dyrness. 1973. Natural vegetation of Oregon and Washington. pp. 53-108. USDA General Technical Report PNW-8, PNW Forest and Range Experiment Station.

Franklin, J.F. and M.A. Hemstrom. 1981. Aspects of succession in the coniferous forests of the Pacific Northwest. In D.C. West, H. Shugart and D.B. Botkin (eds.). Forest succession: concepts and application. pp. 212-229. Springer Verlag, New York, NY, USA.

Franklin, J.F., T.A. Spies, R. Van Pelt, A.B. Carey, D.A. Thornburgh, D.R. Berg, D.B. Lindenmayer, M.E. Harmon, W.S. Keeton, D.C. Shaw, K. Bible and J. Chen. 2002. Disturbances and structural development of natural forest ecosystems with silvicultural implications, using Douglas-fir forests as an example. Forest Ecology and Management 155: 399-423.

Glenn-Lewin, D.C., R.K. Peet and T.T. Veblen. 1992. Plant succession: theory and prediction, Chapman and Hall, New York, NY, USA.

Gregory, R.A. 1957. Some silvicultural characteristics of western redcedar of southeast Alaska. Ecology 38: 646-649.

Harmon, M.E. 1992. Long-term experiments on log decomposition at the H.J. Andrews Experimental Forest. Available from USDA Forest Service PNW Research Station, Portland, Oregon. General Technical Report PNW-GTR-280.

Holmes, R.L. 1986. Quality control of crossdating and measuring: a user's manual for program COFECHA. In R.I. Holmes. R.K Adams and H.C. Fritts, H.C. (eds.). Tree-ring chronologies of western North America: California, Eastern Oregon and Northern Great Basin. pp 41-49. University of Arizona Press, Tucson, AZ., USA.

Keenan, R. 1993. Structure and function of western redcedar and western hemlock forests on northern Vancouver Island. Ph.D. Thesis, Department of Forestry, University of British Columbia, Vancouver, B.C. 167 p.

Keenan, R.J., C.E. Prescott and J.P. Kimmins. 1993. Mass and nutrient content of woody debris and forest floor in western redcedar and western hemlock forests on northern Vancouver Island. Canadian Journal of Forest Research 23: 1052-1059.
Kelsey, R.G. and M.E. Harmon. 1989. Distribution and variation of extractable total phenols and tannins in the logs of four conifers after 1 year on the ground. Canadian Journal of Forest Research 19: $1030-1036$

Klinka, K., R.E. Carter and M.C. Feller. 1990. Cutting old-growth forests in British Columbia: ecological consideration for forest regeneration. Northwest Environment Journal 6: 221-242.

Klinka, K. and M.C. Feller. 1993. Regeneration of western redcedar in the Very Wet Maritime Coastal Western Hemlock subzone. 1992/93 Progress Report, British Columbia Ministry of Forests, Vancouver Forest Region, Burnaby, B.C. 11 p.

Klinka, K., J. Pojar and D.V. Meidinger. 1991. Revision of the biogeoclimatic units of coastal British Columbia. Northwest Science 65: 32-47.

Klinka, K., Q. Wang, G.J.K. Kayahara and B.A. Blackwell. 1992. Light-growth relationships in Pacific silver fir (Abies amabilis) and subalpine fir (Abies lasiocarpa). Canadian Journal of Botany 70: 1919-1930.

Krajina, V.J. 1969. Ecology of forest trees in British Columbia. Ecology of Western North America 2: 1-152.

Kuiper, L.C. 1988. The structure of natural Douglas-fir forests in western Washington and western Oregon. Agricultural University, Wageningen (Netherlands) Papers 88-5. 45 p.

Landers, P.B., P. Morgan and F.J. Swanson. 1999. Overview of the use of natural variability concepts in managing ecological systems. Ecological Applications 9: 1179-1188.

Lertzman, K.P. 1992. Patterns of gap-phase replacement in a subalpine, old-growth forest. Ecology 73: 657-669.

Lertzman, K.P. and C.J. Krebs. 1991. Gap-phase structure of a subalpine old growth forest. Canadian Journal of Forest Research 21 1730-1741.

Lertzman, K., T. Spies and F. Swanson. 1997. From ecosystem dynamics to ecosystem management. In P. Schoonmaker, E. Kellogg and T. Wolf (eds.). People and environments of the coastal temperate rainforest. pp. 361-382. Island Press, Washington, D.C., USA

Lertzman, K.P., G.D. Sutherland, A. Inselberg and S.C. Saunders. 1996. Canopy gaps and the landscape mosaic in a temperate rainforest. Ecology 77: 1254-1270.

Lorimer, C.G. and L.E. Frelich. 1989. A methodology for estimating canopy disturbance frequency and intensity in dense temperate forests. Canadian Journal of Forest Research 19: 651-663.

Munger, T.T. 1940. The cycle from Douglas fir to hemlock. Ecology 21: 451-459.

Nault, J. 1988. Radial distribution of thujaplicins in old growth and second-growth western redcedar (Thuja plicata Donn). Wood Science Technology 22: 73-80.

Norusis, M.J. 1994. SPSS Advanced statistics 6.1. SPSS Inc. Chicago IL., USA.

Oliver, C.D. 1981. Forest development in North America following major disturbances. Forest Ecology and Management 3: 153-168. Oliver, C.D. and B.C. Larson. 1990. Forest stand dynamics. McGraw-Hill, New York, NY., USA.

Orwig, D.A. and M.D. Abrams. 1994. Contrasting radial growth and canopy recruitment patterns in Liriodendron tulipifera and Nyssa sylvatica: gap-obligate versus gap-facultative species. Canadian Journal of Forest Research 24: 2141-2149.

Payette, S., L. Filion and A. Delwaide. 1990. Disturbance of a cold temperate forest as deduced from tree-ring patterns: the Tantare Ecological Reserve, Quebec. Canadian Journal of Forest Research 20: 1228-1241.

Pickett, S.T.A., S.L. Collins and J.J. Armesto. 1987. A hierarchical consideration of causes and mechanisms of succession. Vegetatio 69: 109-114.

Pickett, S.T.A. and J. Kolasa. 1989. Structure of theory in vegetation science. Vegetatio 83: 7-15. 
Pickett. S.T.A., V.T. Parker and P.L. Fiedler. 1992. The paradigm in ecology: implications for conservation biology above the species level. In P.L. Fiedler and S.K. Jain (eds.). Conservation biology: theory and practice of nature conservation, preservation and management pp. 50-65. Chapman Hall, New York, NY.

Pickett, S.T.A. and P.S. White. (eds.). 1985. The ecology of natural disturbance and patch dynamics. Academic Press, New York, NY. Pojar, J., K. Klinka and D.A. Demarchi. 1991. Coastal western hemlock zone. In D.V. Meidinger and J. Pojar (eds.). Ecosystems of British Columbia. pp. 95-111. British Columbia Ministry of Forests Special Report Series 6. Victoria, B.C.

Pojar, J., C. Rowan, A. MacKinnon, D. Coates and P. LePage. 1999. Silvicultural options in the central coast. Land Use Coordination Office, Victoria, B.C

Schmidt, R.L. 1955. Some aspects of western redcedar regeneration in the coastal forests of British Columbia. British Columbia Department of Lands and Forests, Research Note 29. Victoria, B.C. 10 p. Schupp, E.W., H.F. Howe, C.K. Augspurger and D.J. Levey. 1989. Arrival and survival in tropical treefall gaps. Ecology 70: 562-564 Scientific Panel for Sustainable Forest Practices in Clayoquot Sound. 1995. Report 5: sustainable ecosystem management in Clayoquot Sound: planning and practices. Victoria, B.C.

Sollins, P., S.P. Cline, T. Verhoeven, D. Sachs and G. Spycher. 1987. Patterns of log decay in old-growth Douglas-fir forests. Canadian Journal of Forest Research 17: 1585-1595.

Sousa, W.P. 1984. The role of disturbance in natural communities. Annual Review of Ecological Systems 15: 353-391.
Spies, T.A., J.F. Franklin and M. Klopsch. 1990. Canopy gaps in Douglas-fir forests of the Cascade Mountains. Canadian Journal of Forest Research 20: 649-658.

Stokes, M.A. and T.L. Smiley. 1968. An introduction to tree ring dating. University of Chicago Press, Chicago, IL.

Thomas, J.W., R.G. Anderson, C. Maser and E.L. Bull. 1979. Snags. In USDA Forest Service Agricultural Handbook 533. pp. 60-77.Washington D.C., USA.

Turner, D.P. and E.H. Franz. 1985. Size class structure and tree dispersion patterns in old-growth cedar-hemlock forests of the northern Rocky Mountains (USA). Oecologia 68: 52-56.

van der Kamp, B. J. 1986. Effects of heartwood inhabiting fungi on thujaplicin content and decay resistance of western redcedar (Thuja plicata Donn). Wood Fiber Science 18: 421-427.

Veblen, T.T. 1992. Regeneration dynamics. In D.G. Glenn-Lewin, R.K. Peet and T.T. Veblen (eds.). Plant succession: theory and prediction. pp. 152-187. Chapman Hall, New York, NY.

Wells, R.W., K.P. Lertzman and S.C. Saunders. 1998. Old-growth definitions for the forests of British Columbia, Canada. Natural Areas Journal 18: 279-292.

White, P.S. 1979. Pattern, process, and natural disturbance in vegetation. Botanical Review 45: 229-299.

Yamaguchi, D.K. 1991. A simple method for cross-dating increment cores from living trees. Canadian Journal of Forest Research 21: 414-416. 